\title{
Key Issues Surrounding Appropriate Antibiotic Use for Prevention of Surgical Site Infections in Low- and Middle-Income Countries: A Narrative Review and the Implications
}

This article was published in the following Dove Press journal:

International Journal of General Medicine

Julius $C$ Mwita $\mathbb{D}^{\prime}$

Olayinka O Ogunleye $\mathbb{D}^{2,3}$

Adesola Olalekan (1D ${ }^{4,5}$

Aubrey $C$ Kalungia $(\mathbb{D})^{6}$

Amanj Kurdi $\mathbb{I D}^{7,8}$

Zikria Saleem (1D ${ }^{9}$

Jacqueline Sneddon ${ }^{10}$

Brian Godman (D) $7,11,12$

'Department of Internal Medicine, Faculty of Medicine, University of Botswana,

Gaborone, Botswana; ${ }^{2}$ Department of

Pharmacology, Therapeutics and Toxicology,

Lagos State University College of Medicine,

Lagos, Nigeria; ${ }^{3}$ Department of Medicine,

Lagos State University Teaching Hospital,

Lagos, Nigeria; ${ }^{4}$ Department of Medical

Laboratory Science, University of Lagos,

Lagos, Nigeria; ${ }^{5}$ Centre for Genomics of

Non-Diseases and Personalized Healthcare (CGNPH), University of Lagos, Lagos,

Nigeria; ${ }^{6}$ Department of Pharmacy,

University of Zambia, Lusaka, Zambia;

${ }^{7}$ Strathclyde Institute of Pharmacy and

Biomedical Sciences, Strathclyde University,

Glasgow, UK; ${ }^{8}$ Department of

Pharmacology, College of Pharmacy, Hawler

Medical University, Erbil, Iraq; ' Department

of Pharmacy Practice, Faculty of Pharmacy,

The University of Lahore, Lahore, Pakistan;

${ }^{10}$ Healthcare Improvement Scotland,

Glasgow, UK; "'School of Pharmacy, Sefako

Makgatho Health Sciences University,

Pretoria, South Africa; ${ }^{12}$ School of

Pharmaceutical Sciences, Universiti Sains

Malaysia, Penang, Malaysia

Correspondence: Brian Godman

Strathclyde Institute of Pharmacy and

Biomedical Sciences, University of

Strathclyde, Glasgow, UK

Tel +44 I4I 5483825

Email Brian.godman@strath.ac.uk
Background: There is a concern with the growing use of antimicrobials across countries increasing antimicrobial resistance (AMR) rates. A key area within hospitals is their use for the prevention of surgical site infections (SSI) with concerns with timing of the first dose, which can appreciably impact on effectiveness, as well as duration with extended prophylaxis common among low- and middle-income countries (LMICs). This is a concern as extended duration increases utilization rates and AMR as well as adverse events. Consequently, there is a need to document issues of timing and duration of surgical antibiotic prophylaxis (SAP) among LMICs together with potential ways forward to address current concerns.

Methods: Narrative review of timings and duration of SAP among LMICs combined with publications documenting successful approaches to improve SAP to provide future direction to all key stakeholder groups.

Results: There were documented concerns with the timing of the first dose of antibiotics, with appropriate timing as low as $6.7 \%$ in Egypt, although as high as $81.9 \%$ in Turkey. There was also an extensive duration of SAP, ranging from long duration times in all patients in a study in Nigeria with a mean of 8.7 days and $97 \%$ of patients in Egypt to $42.9 \%$ of patients in Pakistan and $35 \%$ in Turkey. Successful interventions to improve SAP typically involved multiple approaches including education of all key stakeholder groups, monitoring of usage against agreed guidelines, as well as quality targets. Multiple approaches typically improved timing and duration as well as reduced costs. For instance, in one study appropriateness increased from $30.1 \%$ to $91.4 \%$, prolonged duration reduced to $5.7 \%$ of patients, and mean costs of antibiotics decreased 11 -fold. Conclusion: There are considerable concerns with the timing and duration of SAP among LMICs. Multiple interventions among LMICs can address this providing future directions.

Keywords: surgical site infections, antibiotic prophylaxis, timing of prophylaxis, duration of prophylaxis, LMICs, quality indicators

\section{Introduction}

Globally, utilization of antibiotics rose by 39\% between 2000 and 2015, which has been driven mainly by increasing consumption in lower- and middle-income (LMIC) countries. ${ }^{1-3}$ This is a concern as rising rates will increase antimicrobial resistance (AMR), increasing morbidity, mortality, and costs. ${ }^{4-7}$

One of the key areas to reduce inappropriate prescribing of antibiotics in hospitals surrounds their use in preventing surgical site infections (SSIs). ${ }^{8}$ SSIs 
are categorized as infections related to a given operative procedure that occurs at or near the surgical incision within 30 days of the procedure or longer if a prosthesis is implanted, and affects either the incision or deep tissue at the operation site or any part of the surrounding anatomy such as pertinent organs or spaces. ${ }^{9-11}$ They are currently the most common infectious complications seen among hospitalized patients in developing countries, ${ }^{12,13}$ and are among the most common and costly causes of hospital acquired infections (HAIs), especially in LMICs. ${ }^{14-22}$ SSIs can also account for appreciable antibiotic use in hospitals. ${ }^{23-26}$ Costs associated with SSIs are enhanced by associated increases in the length of hospital stay, which is in addition to increasing morbidity and mortality. ${ }^{15,-27-29}$ Published studies suggest consolidated incidence figures for SSIs for Nigeria and across Africa at between $14.5-14.8 \%$ of all operations, ${ }^{12,30}$ with rates typically higher in LMICs vs high-income countries. ${ }^{13,-30-35}$ Consequently, there is an urgent need to improve their prevention in LMICs.

Recognized measures to reduce SSIs include surgical hand preparation, antiseptic preparation, coated sutures, wound protector devices, and negative-pressure wound dressings. ${ }^{18,-29,-36-38}$ In addition, improving the quality of surgery through increased education as well as the development and monitoring of pertinent quality indicators (QIs). ${ }^{39-41}$ Measures also include administering antimicrobial prophylaxis, which is seen as the single most effective intervention to reduce SSI rates. ${ }^{42}$ The selection of antibiotics for SSIs is often based on the risk of wound infection according to the wound classification, ie, clean, clean-contaminated, contaminated, or dirty-infected, the normal floral distribution of the site to be operated on, and local antibiotic resistance patterns. ${ }^{14,43,44}$ Broad-spectrum antibiotics are often preferred to narrow spectrum antibiotics, and cephalosporins are commonly used. ${ }^{27,-45-47}$ For instance, cefazolin is commonly recommended for the gastroenterological, genitourinary tract, and hepatobiliary surgeries. ${ }^{48}$ Ideally, administration of the first antibiotic dose should be within 60 minutes of the first incision, longer for vancomycin and the fluoroquinolones, with a second dose administered for long procedures. ${ }^{18,-42,-49-51}$ Vicentini et $\mathrm{al}^{8}$ found that adequate antibiotic choices and length of administration were associated with significantly reduced risks of SSIs. Overall, published studies have shown that the risk of SSIs is almost 5-times higher when antibiotics are administered more than 120 minutes prior to the first incision and almost doubled when antibiotics are administered after the first incision. ${ }^{52}$ Extending prophylaxis beyond 1 day also does not appear to improve patient outcomes, whilst at the same time increasing the chances of acute kidney injury, Clostridium difficile infections, AMR, and costs. ${ }^{13,-42,-53-56}$

We are aware that there can be poor compliance to current guidelines when available to prevent SSIs across LMICs and wider. ${ }^{45,-57-62}$ This is in addition to the lack of antibiotic guidelines generally in some hospitals. ${ }^{63}$ For instance, Madubueze et $\mathrm{al}^{59}$ found that compliance with surgical antibiotic prophylaxis (SAP) protocols among orthopedic surgeons in Nigeria was only $30.3 \%$ of situations. Reasons for poor compliance to guidelines included following old practices (25\%), concerns that the hospitals were not sufficiently clean $(27.3 \%)$, and proper aseptic techniques were not being followed (27.3\%). ${ }^{59}$ Other reasons for poor compliance include overcrowding in hospitals, resistance to change among physicians, poor knowledge regarding antibiotics among physicians, and concerns with malnutrition in some patients. ${ }^{45,50,64}$ Patient expectations may also play an important factor in decision-making. ${ }^{50,65}$

Principal areas of concern with current SAP approaches across countries including LMICs include timing of administration as well as prolonged use postsurgery. ${ }^{23,45,66,67}$ Consequently, we believe there is a need to document issues regarding the current timing of administration and the duration of antibiotic administration for SAP among LMICs as well as debate potential ways forward to improve this. This is because reducing the length of post-operative administration will reduce the extent of broad-spectrum antibiotic use for SAP, which in turn should reduce AMR as well as adverse events. Improved SAP can be part of the agreed National Action Plans as countries move to reduce their AMR rates. ${ }^{68-70}$ This was the objective behind this review article.

\section{Materials and Methods}

We have chosen LMICs as they typically have the highest rates of AMR with concerns with antibiotic prescribing common across countries and sectors. ${ }^{68,-71-73} \mathrm{We}$ are also aware of the challenges involved with implementing quality improvement programs among hospitals in LMICs to improve future antibiotic prescribing, which include manpower and resource issues as well as physician resistance as part of any antibiotic stewardship program(ASP). ${ }^{74,75}$ ASPs are important as they can appreciably improve 
antibiotic use in hospitals and reduce costs. ${ }^{74,76}$ These challenges with improving the appropriate use of antibiotics in hospitals are exacerbated by variable knowledge regarding antibiotics, AMR, and ASPs among clinicians in LMICs. $^{73,-77-85}$ Consequently, we will look to build upon successful approaches to improve SAP instigated among LMICs to give guidance on potential ways forward to address concerns where these continue to exist. ${ }^{50,86}$

The first step will be to document timings and the duration of antibiotic administration for SAP among a range of LMICs before documenting interventions that have been successful with improving SAP among LMICs. This will involve a narrative review of the published literature. The findings will be combined with the extensive experience of the senior-level co-authors to provide future guidance on potential ways to enhance SAP among LMICs including lessons generally from a range of former Soviet Union Republics that have variably instigated initiatives to reduce inappropriate prescribing of antibiotics. We have chosen former Soviet Union Republics as they typically have less Gross Domestic Product (GDP) per capita than among higher income Western European countries, ${ }^{87}$ ie, more akin to LMICs.

We did not undertake a systematic review since we were aware that there had been a number of reviews surrounding the use of antibiotic prophylaxis as well as other potential interventions to reduce SSIs. ${ }^{29,-50,-52,-86,-88-93}$ In addition, our aim was to provide possible guidance for key stakeholder groups within LMICs based on our experiences for potential debate. We have successfully used this approach across LMICs to stimulate debate in different key disease areas and topics. ${ }^{68,-94-97}$

The interventions that have been undertaken and proposed will be broken down into the 4Es where pertinent, namely Education, Engineering, Economics, and Enforcement, ${ }^{98,99}$ to enhance understanding and comparisons given the range of potential interventions that could be instigated. Education includes developing guidelines or formularies, with adherence to well-constructed guidelines increasingly seen as indicating good quality care. ${ }^{25,-100-103}$ Activities within hospitals to enhance the rational use of medicines are typically co-ordinated by Drug and Therapeutic Committees (DTCs). ${ }^{104-106}$ Antimicrobial stewardship groups may be part of DTCs; alternatively, separate groups working in the hospital as part of infection, prevention, and control groups. ${ }^{107,108}$ In addition, the development and dissemination of the WHO AWaRe list of antibiotics to improve future antibiotic prescribing and dispensing. ${ }^{109,110}$ Engineering includes organizational or managerial interventions such as instigating and monitoring prescribing targets and quality targets. ${ }^{99,100}$ Quality targets could include the percentage of antibiotics prescribed according to agreed guidance, the percentage of antibiotics prescribed within a specified time and for an agreed length to prevent SSIs, as well as monitoring drug and therapeutic committee (DTC) activities against agreed performance indicators. ${ }^{59,102,111}$ Economics includes financial incentives to hospitals, physicians, pharmacists, or patients, ie, providing financial incentives to hospitals to improve patient safety and not pay for preventable errors, to physicians for attaining agreed prescribing targets, and fining pharmacists for illegally dispensing an antibiotic without a prescription. ${ }^{99,100,112,113}$ Enforcement includes regulations by law. ${ }^{99}$ Examples include laws banning the dispensing of antibiotics in pharmacies without a prescription as well as national policies outlining the existence of DTCs in hospitals as currently seen in South Africa. ${ }^{105,114}$

\section{Results}

\section{Timing and Duration of Administration for SAP Among LMICs}

Table 1 documents a range of timings and duration of administration for SAP among LMICs across continents. Ideally, administration of the first antibiotic dose should be within 60 minutes of the first incision and only for 1 day. However, wide variations were seen with only a limited number of patients across a range of LMICs generally receiving SAP within this time (Table 1). Documented rates for staying within agreed timings of the first incision ranged from as low as $6.7 \%$ of patients in Egypt, up to $81.9 \%$ in Turkey.

There were similar concerns regarding the extent of prophylactic antibiotics given for longer than 1 day across LMICs. Rates of extended prophylaxis ranged from all patients in Nigeria in the study by Abubakar et al (2018) with a mean of 8.7 days, to $97 \%$ of patients in Egypt and Pakistan (Saied et al 2015 and Saleem et al 2019, respectively), and $86.3 \%$ among surgical patients in Eastern Europe (part of the Global PPS study). Extended prophylaxis was seen in $42.9 \%$ of patients in Pakistan (Butt et al 2019) and 35\% in Turkey (Ozgun et al 2020) (Table 1).

\section{Interventions to Enhance Adherence to SAPs Among Countries}

A number of interventions have been instigated across many LMICs to improve SAP broken down into 
Table I Published Rates Regarding Inappropriate Timing and Length of Administration of Antibiotics for SAP Among LMICs

\begin{tabular}{|c|c|c|}
\hline Country & Author and Year & Findings \\
\hline $\begin{array}{l}\text { Global PPS including } \\
\text { many LMICs }\end{array}$ & $\begin{array}{l}\text { Versporten et al, } \\
2018^{25}\end{array}$ & $\begin{array}{l}\text { - Prolonged surgical prophylaxis, ie, }>I \text { day was very common in all regions of the world } \\
\text { - The highest rates of extended prophylaxis were seen in Eastern Europe (LMICs) - 86.3\% of } \\
\text { patients }\end{array}$ \\
\hline \multirow[t]{2}{*}{ Botswana } & Mwita et al, $2018^{\prime \prime}$ & $\begin{array}{l}\text { - Poor timing of prophylaxis was common, with only } 15 \% \text { of surgical patients receiving antibiotics } \\
\text { pre-operatively, } 58.3 \% \text { post-surgery, and } 26.8 \% \text { of patients were not prescribed any antibiotics } \\
\text { - Prolonged surgical prophylaxis was common, with the mean (SD) duration of post-operative } \\
\text { antibiotic use being } 5 \text { (2.6) days }\end{array}$ \\
\hline & $\begin{array}{l}\text { Anand Paramadhas } \\
\text { et al, } 2019^{115}\end{array}$ & $\begin{array}{l}\text { Extended prophylaxis (>I day) was common. However, the extent among patients varied across } \\
\text { hospital types: } \\
\text { - Specialist }-66.7 \% \text { of patients } \\
\text { - Tertiary }-100 \% \text { of patients } \\
\text { - District }-90.3 \% \text { of patients } \\
\text { - Primary }-100 \% \text { of patients }\end{array}$ \\
\hline China & Yang et al, $2014^{51}$ & $\begin{array}{l}\text { Poor timing of the initial antibiotic dose, ie, outside of } 30 \text { minutes to } 2 \text { hours pre-incision, was } \\
\text { common and seen in } 67.1 \% \text { of patients }\end{array}$ \\
\hline \multirow[t]{2}{*}{ Egypt } & Talaat et al, $2014^{116}$ & $\begin{array}{l}\text { Poor timing and prolonged use of antibiotics was common among surgical patients in this PPS } \\
\text { study: } \\
\text { - } 72 \% \text { of surgical patients did not receive their first dose of antibiotics within } 2 \text { hours before the } \\
\text { incision } \\
\text { - } 75 \% \text { of patients received surgical prophylaxis for }>24 \text { hours }\end{array}$ \\
\hline & Saied et al, $2015^{117}$ & $\begin{array}{l}\text { - Poor timing of SAP was common, with } 92.3 \% \text { of patients receiving the first dose of antibiotics } \\
\text { outside of the agreed optimal time among three hospitals surveyed prior to educational and } \\
\text { other interventions } \\
\text { - All hospitals surveyed showed a significant improvement in the optimal duration of SAP post- } \\
\text { intervention - increasing from } 3 \% \text { of patients to } 28 \%(P<0.01)\end{array}$ \\
\hline Ethiopia & Halawi et al, $2018^{47}$ & $\begin{array}{l}\text { - } 62.2 \% \text { of patients received SAP longer than I hour pre-operatively } \\
\text { - } 88.9 \% \text { of patients received antimicrobial prophylaxis for greater than } 24 \text { hours after surgery }\end{array}$ \\
\hline Ghana & Afriyie et al, $2020^{63}$ & $\begin{array}{l}\text { The duration of antibiotic use for SAP was generally more than I day }-69.0 \% \text { in one hospital and } \\
77.0 \% \text { in another }\end{array}$ \\
\hline \multirow[t]{3}{*}{ Kenya } & $\begin{array}{l}\text { Ntumba et al, } \\
2015^{118}\end{array}$ & $\begin{array}{l}50 \% \text { of patients in this study received post-operative antibiotics before an active intervention to } \\
\text { address high rates }\end{array}$ \\
\hline & Opanga et al, $2017^{67}$ & $\begin{array}{l}\text { The duration of prophylaxis from the onset of surgery for patients with neurotrauma ranged from } \\
\text { I-3 days }\end{array}$ \\
\hline & Okoth et al, $2018^{119}$ & The average number of antibiotic doses in this PPS study for SAP was 19.1 doses \\
\hline India & Shankar, $2018^{61}$ & $\begin{array}{l}\text { All patients operated on on a particular day were administered antibiotics in the morning, } \\
\text { irrespective of the timing of their surgery }\end{array}$ \\
\hline Iran & $\begin{array}{l}\text { Mahmoudi et al, } \\
2019^{27}\end{array}$ & 92.1\% of patients received SAP for more than 48 hours \\
\hline \multirow[t]{2}{*}{ Nigeria } & $\begin{array}{l}\text { Madubueze et al, } \\
2015^{59}\end{array}$ & $57.6 \%$ of orthopedic surgeons gave antibiotic administration outside of I hour prior to surgery \\
\hline & $\begin{array}{l}\text { Abubakar et al, } \\
2018^{64}\end{array}$ & $\begin{array}{l}\text { - Timing of SAP was suboptimal, with } 83.5 \% \text { of patients administered their first dose outside of } \\
\text { the } 60 \text { minute window prior to the first incision } \\
\text { - Prolonged SAP was seen in all patients with a mean duration of } 8.7 \pm 1.0 \text { days }\end{array}$ \\
\hline
\end{tabular}

(Continued) 
Table I (Continued).

\begin{tabular}{|c|c|c|}
\hline Country & Author and Year & Findings \\
\hline & $\begin{array}{l}\text { Oshikoya et al, } \\
2019^{120}\end{array}$ & $\begin{array}{l}\text { - } 97.7 \% \text { of surgical patients received SAP } \\
\text { - However complete compliance to current guidelines on issues such as timing and duration of } \\
\text { antibiotic use was suboptimal in } 94.4 \% \text { of patients }\end{array}$ \\
\hline & $\begin{array}{l}\text { Umeokonkwo et al, } \\
2019^{46}\end{array}$ & Typically, prolonged use of antibiotics for surgical prophylaxis was common \\
\hline & $\begin{array}{l}\text { Fowotade et al, } \\
2020^{121}\end{array}$ & 98.7\% of all antibiotic prescriptions for SAP were given for more than I day \\
\hline \multirow[t]{3}{*}{ Pakistan } & Butt et al, $2019^{45}$ & $\begin{array}{l}\text { - Pre-intervention - incorrect choice of antibiotic }-88.4 \% \text { of occasions } \\
\text { - Duration of antibiotic use }>60 \text { hours }-42.9 \% \text { of occasions }\end{array}$ \\
\hline & Saleem et al, $2019^{122}$ & $\begin{array}{l}97.4 \% \text { of antibiotics prescribed for SAP in this PPS study in the Punjab region were given for more } \\
\text { than I day }\end{array}$ \\
\hline & Satti et al, $2019^{123}$ & $\begin{array}{l}\text { Duration of post-operative prophylaxis for SAP was suboptimal with } 47.3 \% \text { prescribed antibiotics } \\
\text { for }>24 \text { hours }\end{array}$ \\
\hline Rwanda & $\begin{array}{l}\text { Nkurunziza et al, } \\
2019^{60}\end{array}$ & $92 \%$ of SAP patients received post-operative antibiotics for more than 3 days \\
\hline \multirow[t]{3}{*}{ Turkey } & Ozgun et al, $2010^{131}$ & There was prolonged use of antibiotics post-operatively in $35 \%$ of patients \\
\hline & Kaya et al, $2016^{124}$ & Duration of antibiotic use for SAP was inappropriate in $29.1 \%$ of cases \\
\hline & Karaali et al, $2019^{23}$ & $\begin{array}{l}\text { - Surgical prophylaxis }>24 \text { hours }-60.2 \% \text { of patients } \\
\text { - Antibiotic prescribed after discharge }-80.6 \% \text { of patients }\end{array}$ \\
\hline
\end{tabular}

Abbreviations: LMICs, lower- and middle-income countries; PPS, Point Prevalence Survey; SAP, surgical antibiotic prophylaxis.

Education, Engineering, Economics, and Enforcement where pertinent and by year to provide guidance.

Interventions principally centred around educational inputs. In addition, monitoring subsequent prescribing against agreed guidance (QIs) and providing feedback to help improve subsequent SAP (Engineering - Table 2). Multiple interventions resulted in appreciable improvements in SAP across LMICs. For instance, Bozkurt et al (2014) found that multiple interventions improved the duration of prophylaxis from $10.3 \%$ to $59.4 \%$ of cases, Saied et al (2015) that optimal timing of the first dose can be appreciably improved ( $6.7 \%$ to $38.7 \%)$, and Brink et al (2017) that the choice of antibiotic, consistent with agreed guidelines, can be improved to $95.9 \%$ of patients (Table 2).

However, we are aware there are cases where interventions have not always been effective. In their study, Ozgun et $\mathrm{al}^{131}$ instigated a number of measures including analyzing key concerns regarding SAP with individual surgical teams, as well as educational meetings with all key stakeholders during which concerns including timing and duration of antibiotic use were discussed. However, compliance to agreed guidelines actually decreased postintervention, and the number of patients receiving prolonged SAP was higher after the intervention than before, increasing from $34 \%$ of patients (Table 1) to $52 \%$, which was statistically significant $(P<0.01)$, with surgeons comfortable at the time with prolonged administration. ${ }^{131}$

\section{Discussion and Recommendations}

We have shown that there can be considerable concerns regarding the current use of SAP among LMICs to reduce SSIs. These include concerns with both the timing and duration of administration of antibiotics (Table 1). Both need to be addressed to enhance the effectiveness of appropriate SAP to prevent SSIs, reduce the extent of any adverse events including Clostridium difficile infections and AMR, as well as reduce costs. ${ }^{8,-52-55}$

Encouragingly, typically multifaceted interventions appear to be successful in addressing concerns with timing and duration of antibiotic prophylaxis providing direction to others (Table 2). This mirrors the successful impact of multiple interventions instigated by health authorities and others in different disease areas and situations, including 
Table 2 Summary of Published Studies Across Countries Documenting the Impact of Interventions on Subsequent Timing and Length of Antibiotic Administration Among a Range of LMICs

\begin{tabular}{|c|c|c|}
\hline $\begin{array}{l}\text { Author } \\
\text { and Year }\end{array}$ & Intervention & Impact \\
\hline $\begin{array}{l}\text { Gomez } \\
\text { et al, } \\
2006^{125}\end{array}$ & $\begin{array}{l}\text { - Education: Intervention based on education/training } \\
\text { - Engineering/Enforcement: Introduction of a protocol with an } \\
\text { automatic stop for antimicrobial prophylaxis }\end{array}$ & $\begin{array}{l}\text { - Timing of prophylaxis improved from } 55 \% \text { to } 88 \% \text { of patients } \\
(P<0.0 \mathrm{I}) \\
\text { - Adequate duration of prophylaxis increased from } 44 \% \text { to } 55 \% \\
\text { of patients }(P<0.0 \mathrm{I}) \\
\text { - Overall expenditure decreased from US } \$ 10,679 \text { per } 1,000 \\
\text { patient-days to US } \$ 7,686\end{array}$ \\
\hline $\begin{array}{l}\text { Aitken } \\
\text { et al, } \\
2013^{65}\end{array}$ & $\begin{array}{l}\text { Education and Engineering: Developing and implementing a SAP } \\
\text { policy within the hospital }\end{array}$ & $\begin{array}{l}\text { - Appreciable improvement in lack of post-operative prophylac- } \\
\text { tic antibiotics to } 60 \% \text { of patients in week I and } 90 \% \text { in week } 6 \\
\text { following policy implementation }(P<0.000 \mathrm{I}) \\
\text { - Net reduction in the costs for IV antibiotics and associated } \\
\text { consumables of approximately US } \$ 2.50 \text { /operation }\end{array}$ \\
\hline $\begin{array}{l}\text { Bozkurt } \\
\text { et al, } \\
2014^{126}\end{array}$ & $\begin{array}{l}\text { Educational interventions including: } \\
\text { - Series of meetings with physicians from each clinic organized } \\
\text { by the Infection Control Committee } \\
\text { - Daily visits from the Infection Control Nurse as well as regular } \\
\text { visits (twice per week) from an Infectious Diseases Control } \\
\text { Specialist - more if compliance with agreed guidelines was low } \\
\text { - Observations regularly shared with the physicians }\end{array}$ & $\begin{array}{l}\text { - Use of appropriate antibiotics increased from } 51 \% \text { to } 63.4 \% \text { of } \\
\text { cases } \\
\text { - Duration of use improved from } 10.3 \% \text { to } 59.4 \% \text { of cases } \\
\text { - Total cost of antibiotics in the medical units, surgical units, and } \\
\text { ICUs decreased by } 32.5 \%, 38.6 \% \text {, and } 11.1 \% \text {, respectively }\end{array}$ \\
\hline $\begin{array}{l}\text { Yang et al, } \\
2014^{51}\end{array}$ & $\begin{array}{l}\text { Education and Engineering: Introduction of a Drug Rational } \\
\text { Usage Guideline System (DRUGS) vs paper-based guidelines to } \\
\text { enhance adherence to surgical prophylaxis guidelines }\end{array}$ & $\begin{array}{l}\text { - Timing of the initial dose improved from } 32.9 \% \text { instigated } \\
\text { within } 30 \text { minutes to } 2 \text { hours pre-incision to } 85.8 \% \text { (statisti- } \\
\text { cally significant) post-intervention } \\
\text { - Average length of stay decreased from } 7.00 \text { days with paper- } \\
\text { based guidelines to } 2.55 \text { days with DRUGS } \\
\text { - Average cost of antibiotics decreased from } ¥ 3,48 \text { I with paper- } \\
\text { based guidelines to } ¥ 1,693 \text { with DRUGS }\end{array}$ \\
\hline $\begin{array}{l}\text { Kim et al, } \\
2015^{127}\end{array}$ & $\begin{array}{l}\text { Education and Engineering: } \\
\text { - Introduction of a surgical safety checklist in the operating } \\
\text { theater over a week-long period } \\
\text { - Data collection team developed and randomly assigned to } \\
\text { observe } 30 \% \text { of the surgical cases and collect process adher- } \\
\text { ence measures, and feedback the findings }\end{array}$ & $\begin{array}{l}\text { - } 12.7 \% \text { increase in the appropriate use of prophylactic } \\
\text { antibiotics }\end{array}$ \\
\hline $\begin{array}{l}\text { Ntumba } \\
\text { et al, } \\
2015^{118}\end{array}$ & $\begin{array}{l}\text { Education and Engineering: } \\
\text { - Local adaptation of guidelines } \\
\text { - Creation and tools for advocacy, training, and leadership } \\
\text { around appropriate SAP }\end{array}$ & $\begin{array}{l}\text { - Patients receiving antibiotics post-operatively decreased from } \\
50 \% \text { to } 26 \% \\
\text { - Crude SSI rates significantly decreased from } 9.3 \% \text { to } 5 \% \text { of } \\
\text { patients }\end{array}$ \\
\hline $\begin{array}{l}\text { Saied et al, } \\
2015^{117}\end{array}$ & $\begin{array}{l}\text { Education and Engineering: } \\
\text { - 2-day training curriculum } \\
\text { - On-the-job training provided to junior surgeons and residents } \\
\text { - Wall-mounted poster developed to remind prescribers of the } \\
\text { optimal timing and duration of antibiotic administration for } \\
\text { SAP } \\
\text { - Regular audit and feedback meetings orchestrated by the } \\
\text { senior surgeon in the hospital (three of five participating } \\
\text { hospitals) }\end{array}$ & $\begin{array}{l}\text { - The optimal timing of the first dose improved significantly in } \\
\text { three hospitals, increasing from } 6.7 \% \text { to } 38.7 \%(P<0.0 \mathrm{I}) \\
\text { - All hospitals showed a significant rise in the optimal duration } \\
\text { of surgical prophylaxis - overall increase of } 3-28 \%(P<0.0 \mathrm{I})\end{array}$ \\
\hline
\end{tabular}

(Continued) 
Table 2 (Continued).

\begin{tabular}{|c|c|c|}
\hline $\begin{array}{l}\text { Author } \\
\text { and Year }\end{array}$ & Intervention & Impact \\
\hline $\begin{array}{l}\text { Brink et al, } \\
2017^{128}\end{array}$ & $\begin{array}{l}\text { Education and Engineering. Key activities driven by hospital } \\
\text { pharmacists included: } \\
\text { - Recording current SSI rates and developing a SAP "toolkit" } \\
\text { - Testing and revising the SAP guidelines and toolkits at pilot } \\
\text { sites prior to their launch at regional training and institutional } \\
\text { workshops } \\
\text { - Obtaining consensus and endorsement from key professionals } \\
\text { in the hospital through adapting and modifying guidelines } \\
\text { where appropriate } \\
\text { - Choosing at least one or more surgical procedures to audit, } \\
\text { including recording pre-intervention SAP practices and trends } \\
\text { for the chosen surgeries } \\
\text { - Subsequently measure compliance to agreed four process mea- } \\
\text { sures over a 4-week period and feedback }\end{array}$ & $\begin{array}{l}\text { - Timely administration of antibiotics increased to } 56.4 \% \text { of } \\
\text { surgical patients }(P<0.000 \mathrm{I}) \\
\text { - Antibiotic choice consistent with the guidelines increased to } \\
95.9 \% \text { of patients and the duration of prophylaxis was now } \\
\text { appropriate among } 93.9 \% \text { of patients }\end{array}$ \\
\hline $\begin{array}{l}\text { Allegranzi } \\
\text { et al, } \\
2018^{129}\end{array}$ & $\begin{array}{l}\text { Education and Engineering: } \\
\text { - } 5 \text { planned visits to each hospital during the study period } \\
\text { supported by a range of tools } \\
\text { - Local teams identified key areas of concern with preventing } \\
\text { SSIs to concentrate on through monitoring an agreed range of } \\
\text { SAP indicators (six pre-identified ones including skin prepara- } \\
\text { tion and optimal timing of prophylaxis) } \\
\text { - Subsequent launch activities of tools and indicators and mon- } \\
\text { itoring/feedback }\end{array}$ & $\begin{array}{l}\text { - Appropriate use of SAP improved from } 12.8 \% \text { (baseline) to } \\
39.1 \% \text { of patients }(P<0.000 \mathrm{I}) \\
\text { - Cumulative SSI incidence decreased from a baseline of } 8.0 \% \text { to } \\
3.8 \% \text { post-intervention }(P<0.000 \mathrm{I})\end{array}$ \\
\hline $\begin{array}{l}\text { Shankar, } \\
2018^{61}\end{array}$ & $\begin{array}{l}\text { Education and Engineering: } \\
\text { - Agreement among key stakeholders of the key elements of the } \\
\text { WHO checklist to help reduce SSls } \\
\text { - The designated checklist coordinator to confirm that the sur- } \\
\text { gical team has completed its tasks before proceeding to the } \\
\text { next steps }\end{array}$ & $\begin{array}{l}\text { - Prior to implementation all patients operated on on a parti- } \\
\text { cular day were administered antibiotics in the morning, irre- } \\
\text { spective of the timing of their surgery } \\
\text { - The correct practice of administration within I-2 hours of the } \\
\text { incision was seen following the intervention } \\
\text { - In addition, rectification of any concerns that appropriate } \\
\text { surgical patients were not given SAP }\end{array}$ \\
\hline $\begin{array}{l}\text { Abubakar } \\
\text { et al, } \\
2019^{130}\end{array}$ & $\begin{array}{l}\text { Education and Engineering: } \\
\text { - Development and dissemination of an agreed departmental } \\
\text { protocol for SAP, presented and agreed before adoption to } \\
\text { enhance adoption rates } \\
\text { - Educational meetings with key clinicians to enhance uptake of } \\
\text { agreed protocols } \\
\text { - Audit and feedback meetings using baseline data } \\
\text { - Reminders with wall mounted posters }\end{array}$ & $\begin{array}{l}\text { - Patients in the post-intervention period were } 5.6 \text {-times more } \\
\text { likely to receive SAP within } 60 \text { minutes before the incision vs } \\
\text { pre-intervention }(P<0.00 \mathrm{I}) \\
\text { - Rate of redundant antibiotic prescriptions was reduced by } \\
19.1 \%\end{array}$ \\
\hline $\begin{array}{l}\text { Butt et al, } \\
2019^{45}\end{array}$ & $\begin{array}{l}\text { Education and Engineering: } \\
\text { - Results of pre-intervention studies shared with physicians and } \\
\text { nurses } \\
\text { - Subsequently general and specific problems regarding appro- } \\
\text { priate SAP were discussed with concerned personal and } \\
\text { committees to enhance future adherence rates } \\
\text { - Training programs over 10-15 days were conducted by hospi- } \\
\text { tal pharmacists for physicians and nurses }\end{array}$ & $\begin{array}{l}\text { - Appropriateness of prophylactic antibiotics increased from } \\
\text { II.6\% to } 28 \% \\
\text { - Only } 33 \% \text { of patients received extended prophylaxis, ie, >60 } \\
\text { hours, down from } 42.9 \% \text { of patients pre-intervention } \\
(P=0.032) \text { significantly reducing antibiotic costs }(P=0.023) \\
\text { - Average length of hospitalization also fell to an average of } 4.50 \\
\text { days post-intervention vs } 5.4 \text { days pre-intervention, further } \\
\text { reducing costs }\end{array}$ \\
\hline
\end{tabular}

(Continued) 
Table 2 (Continued).

\begin{tabular}{|c|c|c|}
\hline $\begin{array}{l}\text { Author } \\
\text { and Year }\end{array}$ & Intervention & Impact \\
\hline $\begin{array}{l}\text { Karaali } \\
\text { et al, } \\
2019^{23}\end{array}$ & $\begin{array}{l}\text { Education, Engineering, and Enforcement: } \\
\text { - Local guidelines updated by two members of the infection } \\
\text { control committee } \\
\text { - One general surgery team leader was appointed to be respon- } \\
\text { sible for improving SAP as part of ASPs in their group } \\
\text { - Periodic training sessions were planned to supervise and reg- } \\
\text { ulate SAP by surgical team leaders } \\
\text { - It was decided that clean and clean-contaminated cases would } \\
\text { not be given SAP for longer than } 24 \text { hours and that discharge } \\
\text { prescriptions would not include antibiotics. However, no ver- } \\
\text { bal or written sanctions were imposed for abuse }\end{array}$ & $\begin{array}{l}\text { - Compliance with the indication of surgical prophylaxis signifi- } \\
\text { cantly increasing from } 55.6 \% \text { to } 64.5 \% \text { of patients }(P<0.05)- \\
\text { despite differences between surgical types } \\
\text { - Significant reduction in the extent of prolonged antibiotic } \\
\text { prophylaxis, ie, beyond } 24 \text { hours, to just } 7.5 \% \text { post-interven- } \\
\text { tion from } 60.2 \% \text { of patients pre-intervention }(P<0.05) \\
\text { - Extent of antibiotic prescribing after discharge improved, } \\
\text { ie. from } 80.6 \% \text { of patients pre-intervention down to } 9.4 \% \\
\text { post-intervention ( } P<0.05) \\
\text { - However limited impact on the timing of first antibiotic dose- } \\
\text { appropriate timing increasing from } 81.9 \% \text { of patients to } 83.7 \%\end{array}$ \\
\hline $\begin{array}{l}\text { Mahmoudi } \\
\text { et al, } \\
2019^{27}\end{array}$ & $\begin{array}{l}\text { Education and Engineering: } \\
\text { - Revising SAP guidelines following meetings between a clinical } \\
\text { pharmacist and the surgical department, with senior clinical } \\
\text { pharmacists delivering lectures about SAP to key members of } \\
\text { the surgical departments } \\
\text { - Clinical pharmacists participating in ward rounds, attending } \\
\text { recovery rooms, and communicating with surgeons when } \\
\text { guidelines not followed } \\
\text { - Clinical pharmacists providing educational material on SAP to } \\
\text { enhance future care } \\
\text { - Rationality of SAP continually evaluated during the periopera- } \\
\text { tive period in accordance with agreed guidelines, with clinical } \\
\text { pharmacists communicating any concerns directly to relevant } \\
\text { physicians to improve future SAP }\end{array}$ & $\begin{array}{l}\text { - Rate of antibiotic prescribing beyond } 48 \text { hours appreciably } \\
\text { improved to just } 5.7 \% \text { of patients, down from } 92.1 \% \text { of } \\
\text { patients pre-intervention } \\
\text { - Appropriateness of antibiotic use increased to } 91.4 \% \text { of } \\
\text { patients, up from } 30.1 \% \\
\text { - The mean cost of antibiotics decreased more than II-fold and } \\
\text { length of stay from an average of } 5.14 \text { days to } 4.33 \text { days } \\
(P<0.00 \mathrm{I}) \text { post-intervention }\end{array}$ \\
\hline
\end{tabular}

Abbreviations: LMICs, lower- and middle-income countries; ASPs, antimicrobial stewardship programs; PPS, Point Prevalence Survey; SAP, surgical antibiotic prophylaxis; SSIs, surgical site infections.

antibiotics as well as medicines for acid-related stomach disorders, depression, hypertension, and hypercholesterolemia, to improve their prescribing. ${ }^{132-140}$ There have been limited changes in physician prescribing behavior in the absence of such interventions. ${ }^{141-143}$ In addition, we are aware that multiple demand-side measures in former Soviet Union Republics have improved appropriate use of antibiotics. In Azerbaijan, initiatives including Education, Economics, and Enforcement resulted in antibiotic utilization decreasing by $47 \%$ between 2011 and $2015 .^{144}$ In Slovenia, multiple activities including all the 4Es also resulted in antibiotic utilization falling by $31 \%$ between 1999 to $2012,{ }^{137}$ with multiple activities in the Republic of Srpska including all the 4Es resulting in a decreasing trend in antibiotic consumption in recent years, with utilization rates comparable or lower than those seen in neighboring countries. ${ }^{145}$ This contrasts with Poland, where limited activities among the authorities and other groups between 2007 and 2016 resulted in Poland continuing to have one of the highest rates of antibiotic consumption across Europe. ${ }^{146}$ However, we are aware of situations where multiple interventions have not improved SAP. ${ }^{131}$

Potential future activities to improve SAP center around the development of antimicrobial stewardship activities including ASPs which can be part of DTCs within countries and hospitals if not already instigated to address concerns and misconceptions (Table 3). This may include the need for additional educational activities surrounding antibiotics and concerns with hygiene, AMR, and SAP if pertinent, along with the development of any local guidelines and QIs. The outputs from subsequent monitoring of SAP post-intervention, including changes in any agreed QIs, can be used to develop and instigate additional pertinent interventions. This is because we have seen that multiple activities including Education, 
Table 3 Potential Strategies to Improve SAP Within Hospitals in LMICs

\section{Potential Strategies (if Not Being Enacted)}

\section{Health authority/Government - the following (if not already done so):}

\section{a) General/Economics}

- Commitment to reducing inappropriate antibiotic prescribing in hospitals as part of any ongoing/planned NAPs. This will involve resources being made available for instigating/implementing ASPs within hospitals with the appropriate use of SAP a key priority. This could be part of DTC or other activities

b) Education/Engineering

- As part of this:

- Contact key universities within countries concerning current physician, pharmacy, and nurse training regarding antibiotics, AMR, ASPs, and SAP, and seek to address concerns where identified. Subsequently, monitor the situation

- Ascertain current knowledge of key stakeholders within hospitals regarding antibiotics, AMR, ASPs, and SAP, using both quantitative and qualitative approaches to guide future activities - which could include the need for further education and training

- Ascertain current SAP practices within hospitals, especially around key issues of timing and length of administration to guide future activities

- Use the findings from any research activities to develop additional educational and other programs where needed among all key stakeholder groups to further improve SAP as part of any NAP - recognizing that multiple interventions are likely to have greater success (Table 2). This includes the introduction/expansion of ASPs that will be culture- and country-specific, as well as multidisciplinary given concerns in some $\mathrm{LMICs}^{75,77,79}$

- Develop or update current guidelines for SAP with key stakeholder groups and make these readily accessible and easy to use. This could include the availability of guidelines on smartphones and other electronic media where pertinent and possible

- As part of this, seek to introduce routine monitoring of antibiotic resistance patterns within hospitals to refine future SAP guidelines

- Instigate active communication and dissemination of any guidelines - key to enhancing adherence rates along with their ease of use. ${ }^{50,86,103,157,158}$

- Subsequently, monitor SAP prescribing against current guidelines and NAPs, enhanced by auditing current practices based on WHO and other checklists

- Pertinent additional programs could include developing/refining QIs for the setting/country building on WHO checklists as well as other quality initiatives for the prevention of SSIs mindful of the requirements needed to develop robust quality indicators ${ }^{40,41,61,147,159}$

c) Economics/Enforcement

- Potentially review funding for hospitals based on avoidable SSIs and their subsequent impact on morbidity, mortality, and costs Physicians

a) Education

- Ascertain current knowledge and beliefs about antibiotics, SAP, and AMR as well as current SAP practices to ascertain gaps in knowledge/current practices. This includes attitudes and beliefs that lead to prolonged antibiotic administration for SAP

- Subsequently seek to instigate additional educational and other activities to address concerns with SAP where these exist, as well as help instigate ASPs within the hospital if these are lacking - recognizing that multiple interventions including educational interventions are typically more successful than single ones (Table 2$)^{50,86}$

- Seek to instigate/enhance CPD activities once healthcare professionals qualify with the help of relevant societies and the government ${ }^{160}$

- Make sure current national guidelines are readily available and easily accessible in facilities and regularly updated as this is not always the case. This can include the availability of guidelines on smart phones

- In addition, encourage physicians through auditing and other practices to regularly consult national/hospital guidelines about optimal approaches to SAP including timing and duration where there are concerns, as well as monitor their performance.

- Work with microbiologists to regularly update resistance patterns within the hospital to help refine SAP guidelines if needed b) Engineering

- Encourage physicians through auditing and other practices to regularly consult national/hospital guidelines about optimal approaches to SAP including timing where there are concerns, as well as monitor their performance

- Use their knowledge to develop meaningful Qls for their specific setting to improve SAP in the future - building on checklists from the WHO and others together with key stakeholder groups - including other physicians, physician societies, nurse practitioners, hospital pharmacists, and health authorities

- Subsequently introduce agreed Qls, monitor prescribing against agreed targets, refine Qls if needed, as well as seek to instigate additional activities if needed to further enhance adherence to agreed QIs to improve SAP within the hospital

c) Economics

- Potentially seek to reward physicians for adherence to agreed SAP guidelines similar to activities with prescribing in a number of countries as well as achieving agreed $\mathrm{Q} \mid \mathrm{s}^{100,134,161}$ 
Table 3 (Continued).

Potential Strategies (if Not Being Enacted)

d) Enforcement

- Potential activities could surround stopping antimicrobial prescribing for SAP after 24 hours, with potential sanctions for abuse - similar to the situation for self-purchasing of antibiotics in community pharmacies ${ }^{113,114}$

\section{Hospital Pharmacists}

a) Education

- Conduct activities within hospitals to ascertain current knowledge regarding antibiotic use, AMR, and ASPs given concerns that exist including concerns with hygiene, etc., leading to extended prophylaxis to prevent SSIs

- Advocate for additional educational activities among pharmacy students surrounding antibiotics, AMR, ASPs, and SAP where pertinent, as well as seek to instigate/enhance CPD activities among hospital pharmacies with the help of relevant pharmaceutical societies and the government b) Education/Engineering

- Play an active role in the instigation/development of ASPs within hospitals as well as seek to actively research current antibiotic use for SAP and generally regarding antibiotic use including PPS studies. ${ }^{115,162}$ This could be part of DTC activities

- Educate key stakeholders regarding appropriate SAP and pertinent antibiotics including alternatives if drug shortages exist. ${ }^{163}$ Such activities can also be part of DTC activities within hospitals or separate depending on the hospital

- Be involved with the development of pertinent QIs within the hospital to improve future SAP, as well as future monitoring and refining activities. This can include disseminating the findings from current antimicrobial resistance patterns within the hospital to refine future SAP guidelines if needed Infection, prevention, and control co-ordinating personnel (if different, eg, nurses)

a) Education/Engineering

- Help instigate ASPs and research into current SAP activities if not already enacted - including addressing current beliefs that lead to extended use of antibiotics for SAP post-surgery, eg, concerns with hygiene

- Help physicians and hospital pharmacists to improve the use of antibiotics for SAP within the hospital, including pertinent educational activities as well as the development/refinement/monitoring of QI activities

- Use the findings from any research/monitoring activities including those surrounding any developed QIs to further educate and co-ordinate activities within hospitals to improve future SAP. This can also include updated findings regarding resistance patterns within the hospital

- Continue to monitor the impact of any activities on the dose, timing, and length of administration of any antibiotics for SAP and introduce further campaigns if needed

\section{HTA Organizations (where these exist)}

- Can help with the local development of any SAP guidelines building on evidence-based principles and subsequently with the monitoring of adherence to SAP guidelines that are developed

- Potentially research the cost-effectiveness of different potential campaigns to improve SAP within hospitals, building on current information regarding the cost benefits of different activities to improving timings/reduce prolonged administration of antibiotics within hospitals - especially if increased resistance increases the costs of antibiotics used. This includes any Qls developed

Patients and the public (education)

- Instigate health education programs regarding the appropriate use of antibiotics and AMR within in schools, communities and patient groups where needed

- Potentially educate patients and households that extensive use of antibiotics is not necessary to reduce SSls and can be counter-productive, including enhancing future AMR rates

Abbreviations: AMR, antimicrobial resistance; ASPs, antimicrobial stewardship programs; CPD, continual professional development; DTCs, Drug and Therapeutic Committees; LMICs, lower- and middle-income countries; NAP, National Action Plans; PPS, Point Prevalence Survey; QIs, quality indicators; SAP, surgical antibiotic prophylaxis; WHO, World Health Organization.

Engineering, and Enforcement can have a significant impact on both the timing and duration of antibiotic use as part of SAP, impacting on future prevalence and morbidity of SSIs as well as costs (Table 2).

More studies are needed though to assess the costeffectiveness of different interventions as opposed to studies that principally measure individual cost components before and after interventions to provide future guidance (Table 3). In addition, any QI developed needs to be robust, appropriate, measurable, and improve future care, building on examples in other situations as well as suggestions from the WHO and others. ${ }^{25,-61,-147-149}$

We are aware that Health Technology Assessment (HTA) units are less developed in LMICs vs high-income countries and there can be concerns with implementing the findings of HTA analyses. ${ }^{150,151}$ However, this is starting to change in some countries, with suggestions for a more integrative approach. ${ }^{152,153}$ This is important as the outputs from HTA units can help hospitals and governments 
prioritize resources and personnel, with the situation becoming even more imperative post the current COVID-19 and its consequences. ${ }^{97}$ This is important to enhance the rational use of SAP in LMICs. However, HTA as a strategy to curb AMR requires appropriate legislative and institutional frameworks, as well as human and financial resources, to translate any findings into effective implementation and monitoring of health interventions. ${ }^{154}$ In addition, physicians, nurses, and pharmacists must confidently trust any STGs produced to enhance their acceptability and success in curbing AMR. ${ }^{155,156}$ This, complemented by enhancing healthcare worker's knowledge regarding antibiotic use, AMR, and ASPs within hospitals through targeted educational interventions, can improve the rational use of antibiotics.

We are aware of some limitations with this paper. These include the fact that we did not undertake a systematic review for the reasons discussed. We have, though, contextualized the findings to provide direction to key stakeholder groups to improve SAP in LMICs based on the considerable experience of the co-authors. We believe these recommendations are robust based on their experience and knowledge across LMICs.

\section{Conclusion}

We believe this is the first review study to combine a narrative review of the timings and duration of antibiotic use for SAP among LMICs as well as approaches that have been successful in addressing current concerns with SAP to provide future direction. We have shown that there are considerable concerns with current SAP among LMICs, including timing and duration, which is important given rising antimicrobial consumption rates and AMR among LMICs. However, multiple interventions can appreciably improve the situation and reduce costs. As a result, there are multiple activities that all key stakeholder groups can undertake to improve future SAP where important issues have been identified, and we will be monitoring this.

\section{Author Contributions}

All authors contributed to the design and development of the paper through their extensive activities to improve the use of antibiotics within hospitals and wider. All authors critically evaluated the first and subsequent drafts and approved the final version before submission.

\section{Funding}

There was no funding for this paper.

\section{Disclosure}

The authors have no relevant conflicts of interest to declare.

\section{References}

1. Klein EY, Milkowska-Shibata M, Tseng KK, et al. Assessment of WHO antibiotic consumption and access targets in 76 countries, 2000-15: an analysis of pharmaceutical sales data. Lancet Infect Dis. 2020;21:107-115. doi:10.1016/S1473-3099(20)30332-7

2. Klein EY, Van Boeckel TP, Martinez EM, et al. Global increase and geographic convergence in antibiotic consumption between 2000 and 2015. Proc Natl Acad Sci U S A. 2018;115(15):E3463-e70. doi:10.1073/pnas.1717295115

3. Schellack N, Benjamin D, Brink A, et al. A situational analysis of current antimicrobial governance, regulation, and utilization in South Africa. Int $J$ Infect Dis. 2017;64:100-106. doi:10.1016/j. ijid.2017.09.002

4. Bell BG, Schellevis F, Stobberingh E, Goossens H, Pringle M. A systematic review and meta-analysis of the effects of antibiotic consumption on antibiotic resistance. BMC Infect Dis. 2014;14:13. doi:10.1186/1471-2334-14-13

5. Cassini A, Hogberg LD, Plachouras D, et al. Attributable deaths and disability-adjusted life-years caused by infections with antibiotic-resistant bacteria in the EU and the European Economic Area in 2015: a population-level modelling analysis. Lancet Infect Dis. 2019;19(1):56-66. doi:10.1016/S1473-3099(18)30605-4

6. Godman B, Fadare J, Kibuule D, et al. Initiatives across countries to reduce antibiotic utilisation and resistance patterns: impact and implications. In: Arora G, Sajid A, Kalia VC, editors. Drug Resistance in Bacteria, Fungi, Malaria, and Cancer. Cham: Springer International Publishing; 2017:539-576.

7. Hofer U. The cost of antimicrobial resistance. Nat Rev Microbiol. 2019;17(1):3. doi:10.1038/s41579-018-0125-x

8. Vicentini C, Politano G, Corcione S, et al. Surgical antimicrobial prophylaxis prescribing practices and impact on infection risk: results from a multicenter surveillance study in Italy (20122017). Am J Infect Control. 2019;47(12):1426-1430. doi:10.1016/ j.ajic.2019.07.013

9. Weber WP, Marti WR, Zwahlen M, et al. The timing of surgical antimicrobial prophylaxis. Ann Surg. 2008;247(6):918-926. doi:10.1097/SLA.0b013e31816c3fec

10. Young PY, Khadaroo RG. Surgical site infections. Surg Clin North Am. 2014;94(6):1245-1264. doi:10.1016/j.suc.2014.08.008

11. Mwita JC, Souda S, Magafu M, Massele A, Godman B, Mwandri M. Prophylactic antibiotics to prevent surgical site infections in Botswana: findings and implications. Hosp Pract. 2018;46(3):97102. doi:10.1080/21548331.2018.1450605

12. Ngaroua JE, Benet T, Djibrilla Y, Djibrilla Y. [Incidence of surgical site infections in sub-Saharan Africa: systematic review and metaanalysis]. Pan Afr Med J. 2016;24:171. French. doi:10.11604/ pamj.2016.24.171.9754

13. Saito H, Inoue K, Ditai J, Weeks AD. Pattern of peri-operative antibiotic use among surgical patients in a regional referral and teaching hospital in Uganda. Surg Infect (Larchmt). 2020;21 (6):540-546. doi:10.1089/sur.2019.176

14. Anderson DJ, Podgorny K, Berrios-Torres SI, et al. Strategies to prevent surgical site infections in acute care hospitals: 2014 update. Infect Control Hosp Epidemiol. 2014;35(6):605-627. doi:10.1086/ 676022 
15. Zimlichman E, Henderson D, Tamir O, et al. Health care-associated infections: a meta-analysis of costs and financial impact on the US health care system. JAMA Intern Med. 2013;173(22):2039-2046. doi:10.1001/jamainternmed.2013.9763

16. Korol E, Johnston K, Waser N, et al. A systematic review of risk factors associated with surgical site infections among surgical patients. PLoS One. 2013;8(12):e83743. doi:10.1371/journal. pone. 0083743

17. Goyal R, Pal H, Sandhu S, Kumar A, Kosey S, Mehra N. Surveillance method for surgical site infection. Indian J Pharm Pract. 2015;8:54-60. doi:10.5530/ijopp.8.2.2

18. Najjar PA, Smink DS. Prophylactic antibiotics and prevention of surgical site infections. Surg Clin North Am. 2015;95(2):269-283. doi:10.1016/j.suc.2014.11.006

19. Saleem Z, Hassali MA, Godman B, Hashmi FK, Saleem F. A multicenter point prevalence survey of healthcare-associated infections in Pakistan: findings and implications. Am J Infect Control. 2019;47(4):421-424. doi:10.1016/j.ajic.2018.09.025

20. Labi AK, Obeng-Nkrumah N, Owusu E, et al. Multi-centre pointprevalence survey of hospital-acquired infections in Ghana. $J$ Hosp Infect. 2019;101(1):60-68. doi:10.1016/j.jhin.2018.04.019

21. Abubakar U. Antibiotic use among hospitalized patients in northern Nigeria: a multicenter point-prevalence survey. BMC Infect Dis. 2020;20(1):86. doi:10.1186/s12879-020-4815-4

22. Abubakar U. Point-prevalence survey of hospital acquired infections in three acute care hospitals in Northern Nigeria. Antimicrob Resist Infect Control. 2020;9(1):63. doi:10.1186/s13756-02000722-9

23. Karaali C, Emiroglu M, Atalay S, et al. A new antibiotic stewardship program approach is effective on inappropriate surgical prophylaxis and discharge prescription. J Infect Dev Ctries. 2019;13 (11):961-967. doi:10.3855/jidc. 11734

24. Saleem Z, Hassali MA, Godman B, et al. Point prevalence surveys of antimicrobial use: a systematic review and the implications. Expert Rev Anti Infect Ther. 2020;18:897-910. doi:10.1080/ 14787210.2020 .1767593

25. Versporten A, Zarb P, Caniaux I, et al. Antimicrobial consumption and resistance in adult hospital inpatients in 53 countries: results of an internet-based global point prevalence survey. Lancet Global Health. 2018;6(6):e619-e29. doi:10.1016/S2214109X(18)30186-4

26. Al Matar M, Enani M, Binsaleh G, et al. Point prevalence survey of antibiotic use in 26 Saudi hospitals in 2016. J Infect Public Health. 2019;12(1):77-82. doi:10.1016/j.jiph.2018.09.003

27. Mahmoudi L, Ghouchani M, Mahi-Birjand M, Bananzadeh A, Akbari A. Optimizing compliance with surgical antimicrobial prophylaxis guidelines in patients undergoing gastrointestinal surgery at a referral teaching hospital in southern Iran: clinical and economic impact. Infect Drug Resist. 2019;12:2437-2444. doi:10.2147/IDR.S212728

28. de Lissovoy G, Fraeman K, Hutchins V, Murphy D, Song D, Vaughn BB. Surgical site infection: incidence and impact on hospital utilization and treatment costs. Am J Infect Control. 2009;37 (5):387-397. doi:10.1016/j.ajic.2008.12.010

29. De Simone B, Sartelli M, Coccolini F, et al. Intraoperative surgical site infection control and prevention: a position paper and future addendum to WSES intra-abdominal infections guidelines. World $J$ Emerg Surg. 2020;15(1):10. doi:10.1186/s13017-020-0288-4

30. Olowo-Okere A, Ibrahim YKE, Olayinka BO, Ehinmidu JO. Epidemiology of surgical site infections in Nigeria: a systematic review and meta-analysis. Niger Postgrad Med J. 2019;26(3):143151. doi:10.4103/npmj.npmj_72_19

31. Allegranzi B, Bagheri Nejad S, Combescure C, et al. Burden of endemic health-care-associated infection in developing countries: systematic review and meta-analysis. Lancet. 2011;377(9761):228241. doi:10.1016/S0140-6736(10)61458-4
32. Mawalla B, Mshana SE, Chalya PL, Imirzalioglu C, Mahalu W. Predictors of surgical site infections among patients undergoing major surgery at Bugando Medical Centre in Northwestern Tanzania. BMC Surg. 2011;11. doi:10.1186/1471-2482-11-21

33. Rickard J, Beilman G, Forrester J, et al. Surgical infections in lowand middle-income countries: a global assessment of the burden and management needs. Surg Infect (Larchmt). 2020;21(6):478494. doi:10.1089/sur.2019.142

34. Olowo-Okere A, Ibrahim YKE, Sani AS, Olayinka BO. Occurrence of surgical site infections at a tertiary healthcare facility in Abuja, Nigeria: a prospective observational study. Med Sci. 2018;6(3):60. doi:10.3390/medsci6030060

35. Maleknejad A, Dastyar N, Badakhsh M, et al. Surgical site infections in Eastern Mediterranean region: a systematic review and meta-analysis. Infect Dis. 2019;51(10):719-729. doi:10.1080/ 23744235.2019.1642513

36. Ling ML, Apisarnthanarak A, Abbas A, et al. APSIC guidelines for the prevention of surgical site infections. Antimicrob Resist Infect Control. 2019;8(1):174. doi:10.1186/s13756-019-0638-8

37. Rojas-Gutierrez E, Vilar-Compte D. An overview of surgical site infection in low- and middle-income countries: the role of recent guidelines, limitations, and possible solutions. Curr Treat Options Infect Dis. 2019;11(3):300-316. doi:10.1007/s40506-019-00198-1

38. Loftus MJ, Guitart C, Tartari E, et al. Hand hygiene in low- and middle-income countries. Int $J$ Infect Dis. 2019;86:25-30. doi:10.1016/j.ijid.2019.06.002

39. Ng-Kamstra JS, Arya S, Greenberg SLM, et al. Perioperative mortality rates in low-income and middle-income countries: a systematic review and meta-analysis. BMJ Global Health. 2018;3(3): e000810. doi:10.1136/bmjgh-2018-000810

40. Roa L, Citron I, Ramos JA, et al. Cross-sectional study of surgical quality with a novel evidence-based tool for low-resource settings. BMJ Open Qual. 2020;9(1):e000880. doi:10.1136/bmjoq-2019000880

41. Saluja S, Mukhopadhyay S, Amundson JR, et al. Quality of essential surgical care in low- and middle-income countries: a systematic review of the literature. Int J Qual Health Care. 2019;31(3):166172. doi:10.1093/intqhe/mzy141

42. Bull AL, Worth LJ, Spelman T, Richards MJ. Antibiotic prescribing practices for prevention of surgical site infections in Australia: increased uptake of national guidelines after surveillance and reporting and impact on infection rates. Surg Infect (Larchmt). 2017;18(7):834-840. doi:10.1089/sur.2017.119

43. Varley AJ, Sule J, Absalom AR. Principles of antibiotic therapy. Critical Care Pain. 2009;9(6):184-188. doi:10.1093/bjaceaccp/ mkp035

44. Culver DH, Horan TC, Gaynes RP, et al. Surgical wound infection rates by wound class, operative procedure, and patient risk index. National nosocomial infections surveillance system. Am J Med. 1991;91(3):152s-7s. doi:10.1016/0002-9343(91)90361-Z

45. Butt SZ, Ahmad M, Saeed H, Saleem Z, Javaid Z. Post-surgical antibiotic prophylaxis: impact of pharmacist's educational intervention on appropriate use of antibiotics. J Infect Public Health. 2019;12(6):854-860. doi:10.1016/j.jiph.2019.05.015

46. Umeokonkwo CD, Madubueze UC, Onah CK, et al. Point prevalence survey of antimicrobial prescription in a tertiary hospital in South East Nigeria: a call for improved antibiotic stewardship. $J$ Global Antimicrob Resist. 2019;17:291-295. doi:10.1016/j. jgar.2019.01.013

47. Halawi E, Assefa T, Hussen S. Pattern of antibiotics use, incidence and predictors of surgical site infections in a Tertiary Care Teaching Hospital. BMC Res Notes. 2018;11(1):538. doi:10.1186/s13104018-3643-8

48. Bratzler DW, Dellinger EP, Olsen KM, et al. Clinical practice guidelines for antimicrobial prophylaxis in surgery. Surg Infect (Larchmt). 2013;14(1):73-156. doi:10.1089/sur.2013.9999 
49. Malhotra NR, Piazza M, Demoor R, et al. Impact of reduced preincision antibiotic infusion time on surgical site infection rates: a retrospective cohort study. Ann Surg. 2020;271(4):774-780. doi:10.1097/SLA.0000000000003030

50. Cooper L, Sneddon J, Afriyie DK, et al. Supporting global antimicrobial stewardship: antibiotic prophylaxis for the prevention of surgical site infection in low- and middle-income countries (LMICs): a scoping review and meta-analysis. JAC-AMR. 2020;2 (3). doi:10.1093/jacamr/dlaa070.

51. Yang Z, Zhao P, Wang J, et al. DRUGS system enhancing adherence of Chinese surgeons to antibiotic use guidelines during perioperative period. PLoS One. 2014;9(8):e102226. doi:10.1371/ journal.pone.0102226

52. de Jonge SW, Gans SL, Atema JJ, Solomkin JS, Dellinger PE, Boermeester MA. Timing of preoperative antibiotic prophylaxis in 54,552 patients and the risk of surgical site infection: a systematic review and meta-analysis. Medicine. 2017;96(29):e6903. doi:10.1097/MD.0000000000006903

53. Branch-Elliman W, O’Brien W, Strymish J, Itani K, Wyatt C, Gupta $\mathrm{K}$. Association of duration and type of surgical prophylaxis with antimicrobial-associated adverse events. JAMA Surg. 2019;154 (7):590-598. doi:10.1001/jamasurg.2019.0569

54. Harbarth S, Samore MH, Lichtenberg D, Carmeli Y. Prolonged antibiotic prophylaxis after cardiovascular surgery and its effect on surgical site infections and antimicrobial resistance. Circulation. 2000;101(25):2916-2921. doi:10.1161/01.cir.101.25. 2916

55. Hawn MT, Knowlton LM. Balancing the risks and benefits of surgical prophylaxis: timing and duration do matter. JAMA Surg. 2019;154(7):598-599. doi:10.1001/jamasurg.2019.0570

56. Langerman A, Thisted R, Hohmann S, Howell M. Antibiotic and duration of perioperative prophylaxis predicts surgical site infection in head and neck surgery. Otolaryngol Head Neck Surg. 2016;154 (6):1054-1063. doi:10.1177/0194599816634303

57. Musmar SM, Ba'ba H, Owais A. Adherence to guidelines of antibiotic prophylactic use in surgery: a prospective cohort study in North West Bank, Palestine. BMC Surg. 2014;14:69. doi:10.1186/ 1471-2482-14-69

58. Alemkere G, Hawryluk GWJ. Antibiotic usage in surgical prophylaxis: a prospective observational study in the surgical ward of Nekemte referral hospital. PLoS One. 2018;13(9):e0203523. doi:10.1371/journal.pone.0203523

59. Madubueze CC, Umaru H, Alada A. Attitudes of Nigerian orthopaedic surgeons to the use of prophylactic antibiotics. Int Orthop. 2015;39(11):2161-2165. doi:10.1007/s00264-015-2822-7

60. Nkurunziza T, Kateera F, Sonderman K, et al. Prevalence and predictors of surgical-site infection after caesarean section at a rural district hospital in Rwanda. Br J Surg. 2019;106(2):e121-e8. doi: $10.1002 /$ bjs. 11060

61. Shankar R. Implementation of the WHO Surgical Safety Checklist at a teaching hospital in India and evaluation of the effects on perioperative complications. Int J Health Plann Manage. 2018;33 (4):836-846. doi:10.1002/hpm.2533

62. Alahmadi YM, Alharbi RH, Aljabri AK, Alofi FS, Alshaalani OA, Alssdi BH. Adherence to the guidelines for surgical antimicrobial prophylaxis in a Saudi tertiary care hospital. J Taibah Univ Med Sci. 2020;15(2):136-141. doi:10.1016/j.jtumed.2020. 01.005

63. Afriyie DK, Sefah IA, Sneddon J, et al. Antimicrobial Point Prevalence Surveys in two Ghanaian hospitals: opportunities for antimicrobial stewardship. JAC AMR. 2020;1-9.

64. Abubakar U, Syed Sulaiman SA, Adesiyun AG. Utilization of surgical antibiotic prophylaxis for obstetrics and gynaecology surgeries in Northern Nigeria. Int J Clin Pharm. 2018;40(5):10371043. doi:10.1007/s11096-018-0702-0
65. Aiken AM, Wanyoro AK, Mwangi J, Juma F, Mugoya IK, Scott JA. Changing use of surgical antibiotic prophylaxis in Thika Hospital, Kenya: a quality improvement intervention with an interrupted time series design. PLoS One. 2013;8(11):e78942. doi:10.1371/journal.pone.0078942

66. Friedman ND, Styles K, Gray AM, Low J, Athan E. Compliance with surgical antibiotic prophylaxis at an Australian teaching hospital. Am J Infect Control. 2013;41(1):71-74. doi:10.1016/j. ajic.2012.02.012

67. Opanga SA, Mwang'ombe NJ, Okalebo FA, Godman B, Oluka M, Kuria KAM. Determinants of the effectiveness of antimicrobial prophylaxis among neurotrauma patients at a referral hospital in Kenya: findings and implications. Infect Dis Preve Med. 2017;5:169.

68. Godman B, Haque M, McKimm J, et al. Ongoing strategies to improve the management of upper respiratory tract infections and reduce inappropriate antibiotic use particularly among lower and middle-income countries: findings and implications for the future. Curr Med Res Opin. 2020;36(2):301-327. doi:10.1080/030079 95.2019.1700947

69. Saleem Z, Hassali MA, Hashmi FK. Pakistan's national action plan for antimicrobial resistance: translating ideas into reality. Lancet Infect Dis. 2018;18(10):1066-1067. doi:10.1016/S1473-3099(18) 30516-4

70. Ghana Ministry of Health, Ministry of Food and Agriculture, Ministry of Environment, Science, Technology and Innovation, Ministry of Fisheries and Aquaculture Development. Ghana national action plan for antimicrobial use and resistance; 20172021. Available from: http://www.moh.gov.gh/wp-content/uploads/ 2018/04/NAP_FINAL_PDF_A4_19.03.2018-SIGNED-1.pdf. Accessed January 8, 2021.

71. Ayukekbong JA, Ntemgwa M, Atabe AN. The threat of antimicrobial resistance in developing countries: causes and control strategies. Antimicrob Resist Infect Control. 2017;6(1):47. doi:10.1186/ s13756-017-0208-x

72. Kalungia A, Godman B. Implications of non-prescription antibiotic sales in China. Lancet Infect Dis. 2019;19(12):1272-1273. doi:10.1016/S1473-3099(19)30408-6

73. Akpan MR, Isemin NU, Udoh AE, Ashiru-Oredope D. Implementation of antimicrobial stewardship programmes in African countries: a systematic literature review. J Global Antimicrob Resist. 2020;22:317-324. doi:10.1016/j.jgar.2020.03.009

74. Cox JA, Vlieghe E, Mendelson M, et al. Antibiotic stewardship in lowand middle-income countries: the same but different? Clin Microbiol Infect. 2017;23(11):812-818. doi:10.1016/j.cmi.2017.07.010

75. Charani E, Smith I, Skodvin B, et al. Investigating the cultural and contextual determinants of antimicrobial stewardship programmes across low-, middle- and high-income countries-A qualitative study. PLoS One. 2019;14(1):e0209847. doi:10.1371/journal. pone.0209847

76. Nathwani D, Varghese D, Stephens J, Ansari W, Martin S, Charbonneau C. Value of hospital antimicrobial stewardship programs [ASPs]: a systematic review. Antimicrob Resist Infect Control. 2019;8:35. doi:10.1186/s13756-019-0471-0

77. Fadare JO, Ogunleye O, Iliyasu G, et al. Status of antimicrobial stewardship programmes in Nigerian tertiary healthcare facilities: findings and implications. $J$ Global Antimicrob Resist. 2019;17:132-136. doi:10.1016/j.jgar.2018.11.025

78. Engler D, Meyer JC, Schellack N, Kurdi A, Godman B. Compliance with South Africa's antimicrobial resistance national strategy framework: are we there yet? J Chemother. 2021;33(1):2131. doi:10.1080/1120009X.2020.1789389

79. Kalungia AC, Mwambula H, Munkombwe D, et al. Antimicrobial stewardship knowledge and perception among physicians and pharmacists at leading tertiary teaching hospitals in Zambia: implications for future policy and practice. J Chemother. 2019;31(78):378-387. doi:10.1080/1120009X.2019.1622293 
80. Babatola AO, Fadare JO, Olatunya OS, et al. Addressing antimicrobial resistance in Nigerian hospitals: exploring physicians prescribing behavior, knowledge and perception of antimicrobial resistance and stewardship programs. Expert Rev Anti Infect Ther. 2020;1-10. Doi:10.1080/14787210.2021.1829474

81. Firouzabadi D, Mahmoudi L. Knowledge, attitude, and practice of health care workers towards antibiotic resistance and antimicrobial stewardship programmes: a cross-sectional study. J Eval Clin Pract. 2020;26(1):190-196. doi:10.1111/jep.13177

82. Saleem Z, Hassali MA, Hashmi FK, Godman B, Ahmed Z. Snapshot of antimicrobial stewardship programs in the hospitals of Pakistan: findings and implications. Heliyon. 2019;5(7):e02159. doi:10.1016/j.heliyon.2019.e02159

83. Labi AK, Obeng-Nkrumah N, Bjerrum S, et al. Physicians' knowledge, attitudes, and perceptions concerning antibiotic resistance: a survey in a Ghanaian tertiary care hospital. BMC Health Serv Res. 2018;18(1):126. doi:10.1186/s12913-018-2899-y

84. Singh S, Charani E, Wattal C, Arora A, Jenkins A, Nathwani D. The state of education and training for antimicrobial stewardship programs in indian hospitals-a qualitative and quantitative assessment. Antibiotics. 2019;8(1):11. doi:10.3390/antibiotics8010011

85. Hayat K, Rosenthal M, Gillani AH, et al. Perspective of key healthcare professionals on antimicrobial resistance and stewardship programs: a multicenter cross-sectional study from Pakistan. Front Pharmacol. 2020;10:1520. doi:10.3389/ fphar.2019.01520

86. Ariyo P, Zayed B, Riese V, et al. Implementation strategies to reduce surgical site infections: a systematic review. Infect Control Hosp Epidemiol. 2019;40(3):287-300. doi:10.1017/ice.2018.355

87. World Bank. GDP per capita; 2020. Available from: https://data.world bank.org/indicator/NY.GDP.PCAP.CD. Accessed January 8, 2021.

88. Haque M, McKimm J, Godman B, Abu Bakar M, Sartelli M. Initiatives to reduce postoperative surgical site infections of the head and neck cancer surgery with a special emphasis on developing countries. Expert Rev Anticancer Ther. 2019;19(1):81-92. doi:10.1080/14737140.2019.1544497

89. Franco LM, Cota GF, Pinto TS, Ercole FF. Preoperative bathing of the surgical site with chlorhexidine for infection prevention: systematic review with meta-analysis. Am J Infect Control. 2017;45 (4):343-349. doi:10.1016/j.ajic.2016.12.003

90. Shi D, Yao Y, Yu W. Comparison of preoperative hair removal methods for the reduction of surgical site infections: a meta-analysis. J Clin Nurs. 2017;26(19-20):2907-2914. doi:10.1111/jocn.13661

91. Yao R, Tan T, Tee JW, Street J. Prophylaxis of surgical site infection in adult spine surgery: a systematic review. J Clin Neurosci. 2018;52:5-25. doi:10.1016/j.jocn.2018.03.023

92. Schreiber PW, Sax H, Wolfensberger A, Clack L, Kuster SP. The preventable proportion of healthcare-associated infections 2005-2016: systematic review and meta-analysis. Infect Control Hosp Epidemiol. 2018;39(11):1277-1295. doi:10.1017/ ice.2018.183

93. Boonchan T, Wilasrusmee C, McEvoy M, Attia J, Thakkinstian A. Network meta-analysis of antibiotic prophylaxis for prevention of surgical-site infection after groin hernia surgery. $\mathrm{Br} J$ Surg. 2017;104(2):e106-e17. doi:10.1002/bjs.10441

94. Godman B, Basu D, Pillay Y, et al. Review of ongoing activities and challenges to improve the care of patients with type 2 diabetes across Africa and the implications for the future. Front Pharmacol. 2020;11:108. doi:10.3389/fphar.2020.00108

95. Godman B, Grobler C, Van-De-Lisle $M$, et al. Pharmacotherapeutic interventions for bipolar disorder type II: addressing multiple symptoms and approaches with a particular emphasis on strategies in lower and middle-income countries. Expert Opin Pharmacother. 2019;20(18):2237-2255. doi: $10.1080 / 14656566.2019 .1684473$
96. Godman B, McCabe H, Leong $\mathrm{T}$ et al. Fixed dose drug combinations - are they pharmacoeconomically sound? Findings and implications especially for lower- and middle-income countries. Expert Rev Pharmacoecon Outcomes Res. 2020;20(1):1-26. doi:10.1080/ 14737167.2020.1734456

97. Ogunleye OO, Basu D, Mueller D, et al. Response to the Novel Corona virus (COVID-19) pandemic across Africa: successes, challenges, and implications for the future. Front Pharmacol. 2020;11:1205.

98. Wettermark B, Godman B, Jacobsson B, Haaijer-Ruskamp FM. Soft regulations in pharmaceutical policy making: an overview of current approaches and their consequences. Appl Health Econ Health Policy. 2009;7(3):137-147. doi:10.1007/BF03256147

99. Godman B. Health authority activities to enhance the quality and efficiency of medicine use and their impact. Adv Human Biol. 2021;11:11-16.

100. Godman B, Wettermark B, van Woerkom M, et al. Multiple policies to enhance prescribing efficiency for established medicines in Europe with a particular focus on demand-side measures: findings and future implications. Front Pharmacol. 2014;5:106. doi:10.3389/fphar.2014.00106

101. Niaz Q, Godman B, Massele A, et al. Validity of World Health Organisation prescribing indicators in Namibia's primary healthcare: findings and implications. Int J Qual Health Care. 2019;31 (5):338-345. doi:10.1093/intqhe/mzy172

102. Nakwatumbah S, Kibuule D, Godman B, et al. Compliance to guidelines for the prescribing of antibiotics in acute infections at Namibia's national referral hospital: a pilot study and the implications. Expert Rev Anti Infect Ther. 2017;15(7):713-721. doi:10. 1080/14787210.2017.1320220

103. Niaz Q, Godman B, Campbell S, Kibuule D. Compliance to prescribing guidelines among public health care facilities in Namibia; findings and implications. Int J Clin Pharm. 2020;42(4):12271236. doi:10.1007/s11096-020-01056-7

104. Hoffmann M. The right drug, but from whose perspective? A framework for analysing the structure and activities of drug and therapeutics committees. Eur J Clin Pharmacol. 2013;69(Suppl 1):79-87. doi:10.1007/s00228-013-1491-y

105. Matlala M, Gous AGS, Meyer JC, Godman B. Formulary management activities and practice implications among public sector hospital pharmaceutical and therapeutics committees in a South African Province. Front Pharmacol. 2020;11:1267. doi:10.3389/ fphar.2020.01267

106. Matlala M, Gous AG, Godman B, Meyer JC. Structure and activities of pharmacy and therapeutics committees among public hospitals in South Africa; findings and implications. Expert Rev Clin Pharmacol. 2017;10(11):1273-1280. doi:10.1080/17512433.2017. 1364625

107. Mpinda-Joseph P, Anand Paramadhas BD, Reyes G, et al. Healthcare-associated infections including neonatal bloodstream infections in a leading tertiary hospital in Botswana. Hosp Pract. 2019;47(4):203-210. doi:10.1080/21548331.2019.1650608

108. Lee MH, Lee GA, Lee SH, Park YH. Effectiveness and core components of infection prevention and control programmes in long-term care facilities: a systematic review. J Hosp Infect. 2019;102(4):377-393. doi:10.1016/j.jhin.2019.02.008

109. Sharland M, Gandra S, Huttner B, et al. Encouraging AWaRe-ness and discouraging inappropriate antibiotic use-the new 2019 Essential Medicines List becomes a global antibiotic stewardship tool. Lancet Infect Dis. 2019;19(12):1278-1280. doi:10.1016/ S1473-3099(19)30532-8

110. Saleem Z, Hassali MA, Godman B, et al. Sale of WHO AWaRe groups antibiotics without a prescription in Pakistan: a simulated client study. J Pharm Policy Pract. 2020;13(1):26. doi:10.1186/ s40545-020-00233-3 
111. Mashaba TP, Matlala M, Godman B, Meyer JC. Implementation and monitoring of decisions by pharmacy and therapeutics committees in South African public sector hospitals. Expert Rev Clin Pharmacol. 2019;12(2):159-168. doi:10.1080/17512433.2018.1545572

112. Brooks J. US Medicare will stop paying for preventable errors. CMAJ. 2007;177(8):841-842. doi:10.1503/cmaj.071347

113. Alrasheedy AA, Alsalloum MA, Almuqbil FA, et al. The impact of law enforcement on dispensing antibiotics without prescription: a multi-methods study from Saudi Arabia. Expert Rev Anti Infect Ther. 2020;18(1):87-97. doi:10.1080/14787210.2020.1705156

114. Jacobs TG, Robertson J, van den Ham HA, Iwamoto K, Bak Pedersen $\mathrm{H}$, Mantel-Teeuwisse AK. Assessing the impact of law enforcement to reduce over-the-counter (OTC) sales of antibiotics in low- and middleincome countries; a systematic literature review. BMC Health Serv Res. 2019;19(1):536. doi:10.1186/s12913-019-4359-8

115. Anand Paramadhas BD, Tiroyakgosi C, Mpinda-Joseph P, et al. Point prevalence study of antimicrobial use among hospitals across Botswana; findings and implications. Expert Rev Anti Infect Ther. 2019;17(7):535-546. doi:10.1080/14787210.2019.1629288

116. Talaat M, Saied T, Kandeel A, et al. A point prevalence survey of antibiotic use in 18 hospitals in Egypt. Antibiotics. 2014;3(3):450 460. doi:10.3390/antibiotics3030450

117. Saied T, Hafez SF, Kandeel A, et al. Antimicrobial stewardship to optimize the use of antimicrobials for surgical prophylaxis in Egypt: a multicenter pilot intervention study. Am J Infect Control. 2015;43(11):e67-e71. doi:10.1016/j.ajic.2015.07.004

118. Ntumba P, Mwangi C, Barasa J, Aiken A, Kubilay Z, Allegranzi B. Multimodal approach for surgical site infection prevention - results from a pilot site in Kenya. Antimicrob Resist Infect Control. 2015;4 (1):P87. doi:10.1186/2047-2994-4-S1-P87

119. Okoth C, Opanga S, Okalebo F, Oluka M, Baker Kurdi A, Godman B. Point prevalence survey of antibiotic use and resistance at a referral hospital in Kenya: findings and implications. Hosp Pract. 2018;46(3):128-136. doi:10.1080/21548331.2018.1464872

120. Oshikoya KA, Ogunyinka IA, Adamaigbo C, Olowo-Okere A. Surgical antimicrobial prophylaxis and its dose appropriateness among paediatric patients in a Nigerian teaching hospital. J Chemother. 2019;31 (6):329-342. doi:10.1080/1120009X.2019.1615725

121. Fowotade A, Fasuyi T, Aigbovo O, et al. Point prevalence survey of antimicrobial prescribing in a Nigerian hospital: findings and implications on antimicrobial resistance. West Afr J Med. 2020;37 (3):216-220.

122. Saleem Z, Hassali MA, Versporten A, et al. A multicenter point prevalence survey of antibiotic use in Punjab, Pakistan: findings and implications. Expert Rev Anti Infect Ther. 2019;17(4):285-293. doi:10.1080/14787210.2019.1581063

123. Satti MZ, Hamza M, Sajid Z, et al. Compliance rate of surgical antimicrobial prophylaxis and its association with knowledge of guidelines among surgical residents in a tertiary care public hospital of a developing country. Cureus. 2019;11(5):e4776.

124. Kaya S, Aktas S, Senbayrak S, et al. An evaluation of surgical prophylaxis procedures in Turkey: a multi-center point prevalence study. Eurasian $J$ Med. 2016;48(1):24-28. doi:10.5152/ eurasianjmed.2015.15222

125. Gomez MI, Acosta-Gnass SI, Mosqueda-Barboza L, Basualdo JA. Reduction in surgical antibiotic prophylaxis expenditure and the rate of surgical site infection by means of a protocol that controls the use of prophylaxis. Infect Control Hosp Epidemiol. 2006;27 (12):1358-1365. doi:10.1017/S0195941700075305

126. Bozkurt F, Kaya S, Tekin R, et al. Analysis of antimicrobial consumption and cost in a teaching hospital. $J$ Infect Public Health. 2014;7(2):161-169. doi:10.1016/j.jiph.2013.09.007

127. Kim RY, Kwakye G, Kwok AC, et al. Sustainability and long-term effectiveness of the WHO surgical safety checklist combined with pulse oximetry in a resource-limited setting: two-year update from Moldova. JAMA Surg. 2015;150(5):473-479. doi:10.1001/jamasurg.2014.3848
128. Brink AJ, Messina AP, Feldman C, Richards GA, van den Bergh D. From guidelines to practice: a pharmacist-driven prospective audit and feedback improvement model for peri-operative antibiotic prophylaxis in 34 South African hospitals. J Antimicrob Chemother. 2017;72(4):1227-1234. doi:10.1093/jac/dkw523

129. Allegranzi B, Aiken AM, Zeynep Kubilay N, et al. A multimodal infection control and patient safety intervention to reduce surgical site infections in Africa: a multicentre, before-after, cohort study. Lancet Infect Dis. 2018;18(5):507-515. doi:10.1016/S1473-3099 (18)30107-5

130. Abubakar U, Syed Sulaiman SA, Adesiyun AG, Lo TS. Impact of pharmacist-led antibiotic stewardship interventions on compliance with surgical antibiotic prophylaxis in obstetric and gynecologic surgeries in Nigeria. PLoS One. 2019;14(3):e0213395. doi:10.1371/ journal.pone.0213395

131. Ozgun H, Ertugrul BM, Soyder A, Ozturk B, Aydemir M. Perioperative antibiotic prophylaxis: adherence to guidelines and effects of educational intervention. Int J Surg. 2010;8(2):159-163. doi:10.1016/j.ijsu.2009.12.005

132. Godman B, Shrank W, Andersen M, et al. Comparing policies to enhance prescribing efficiency in Europe through increasing generic utilization: changes seen and global implications. Expert Rev Pharmacoecon Outcomes Res. 2010;10(6):707-722. doi:10.1586/ erp. 10.72

133. Godman B, Wettermark B, Miranda J, Bennie M, Martin A, Malmstrom RE. Influence of multiple initiatives in Sweden to enhance ARB prescribing efficiency following generic losartan; findings and implications for other countries. Int J Clin Pract. 2013;67(9):853-862. doi:10.1111/ijcp.12130

134. Martin A, Godman B, Miranda J, et al. Measures to improve angiotensin receptor blocker prescribing efficiency in the UK: findings and implications. J Comp Eff Res. 2014;3(1):41-51. doi:10.2217/cer. 13.83

135. Leporowski A, Godman B, Kurdi A, et al. Ongoing activities to optimize the quality and efficiency of lipid-lowering agents in the Scottish national health service: influence and implications. Expert Rev Pharmacoecon Outcomes Res. 2018;18(6):655-666. doi:10.1080/14737167.2018.1501558

136. Godman B, Kurdi A, McCabe H, et al. Ongoing initiatives within the Scottish National Health Service to affect the prescribing of selective serotonin reuptake inhibitors and their influence. J Comp Eff Res. 2019;8(7):535-547. doi:10.2217/cer-2018-0132

137. Furst J, Cizman M, Mrak J, et al. The influence of a sustained multifaceted approach to improve antibiotic prescribing in Slovenia during the past decade: findings and implications. Expert Rev Anti Infect Ther. 2015;13(2):279-289. doi:10.1586/14787210.2015. 990381

138. Molstad S, Lofmark S, Carlin K, et al. Lessons learnt during 20 years of the Swedish strategic programme against antibiotic resistance. Bull World Health Organ. 2017;95(11):764-773. doi:10.2471/BLT.16.184374

139. Bao L, Peng R, Wang Y, et al. Significant reduction of antibiotic consumption and patients' costs after an action plan in China, 2010-2014. PLoS One. 2015;10(3):e0118868. doi:10.1371/journal. pone. 0118868

140. Godman B, Bishop I, Finlayson AE, Campbell S, Kwon HY, Bennie M. Reforms and initiatives in Scotland in recent years to encourage the prescribing of generic drugs, their influence and implications for other countries. Expert Rev Pharmacoecon Outcomes Res. 2013;13(4):469-482. doi:10.1586/14737167. 2013.820956

141. Godman B, Petzold M, Bennett K, et al. Can authorities appreciably enhance the prescribing of oral generic risperidone to conserve resources? Findings from across Europe and their implications. BMC Med. 2014;12:98. doi:10.1186/1741-7015-12-98 
142. Bennie M, Bishop I, Godman B, et al. Are prescribing initiatives readily transferable across classes: the case of generic losartan in Scotland? Qual Prim Care. 2013;21(1):7-15.

143. Kim Y, Kwon H-Y, Godman B, Moorkens E, Simoens S, Bae S. Uptake of biosimilar infliximab in the UK, France, Japan, and Korea: budget savings or market expansion across countries? Front Pharmacol. 2020;11:970. doi:10.3389/fphar.2020.00970

144. Abilova V, Kurdi A, Godman B. Ongoing initiatives in Azerbaijan to improve the use of antibiotics; findings and implications. Expert Rev Anti Infect Ther. 2018;16(1):77-84. doi:10.1080/14787 210.2018.1417835

145. Bojanic L, Markovic-Pekovic V, Skrbic R, et al. Recent initiatives in the Republic of Srpska to enhance appropriate use of antibiotics in ambulatory care; their influence and implications. Front Pharmacol. 2018;9:442. doi:10.3389/fphar.2018.00442

146. Wojkowska-Mach J, Godman B, Glassman A, et al. Antibiotic consumption and antimicrobial resistance in Poland; findings and implications. Antimicrob Resist Infect Control. 2018;7(1):136. doi:10.1186/s13756-018-0428-8

147. Campbell SM, Godman B, Diogene E, et al. Quality indicators as a tool in improving the introduction of new medicines. Basic Clin Pharmacol Toxicol. 2015;116(2):146-157. doi:10.1111/bcpt.12295

148. Robertson J, Iwamoto K, Hoxha I, et al. Antimicrobial medicines consumption in Eastern Europe and Central Asia - an updated cross-national study and assessment of quantitative metrics for policy action. Front Pharmacol. 2019;9:1156. doi:10.3389/ fphar.2018.01156

149. Le Maréchal M, Tebano G, Monnier AA, et al. Quality indicators assessing antibiotic use in the outpatient setting: a systematic review followed by an international multidisciplinary consensus procedure. J Antimicrob Chemother. 2018;73(suppl_6):vi40-vi9. doi:10.1093/jac/dky117

150. Ghassemi S, Dehnavieh R. Applying the results of Health Technology Assessment reports in developing countries, the pale face of coin. Technol Health Care. 2016;24(5):781-782. doi:10.3233/THC-161233

151. Oortwijn W, van Oosterhout S, Kapiriri L. Application of evidenceinformed deliberative processes in health technology assessment in low- and middle-income countries. Int J Technol Assess Health Care. 2020;1-5.

152. Dehnavieh R, Noori Hekmat S, Ghasemi S, Mirshekari N. The vulnerable aspects of application of "Health Technology Assessment". Int J Technol Assess Health Care. 2015;31(3):197198. doi:10.1017/S0266462315000288

153. Oortwijn W, Determann D, Schiffers K, Tan SS, van der Tuin J. Towards integrated health technology assessment for improving decision making in selected countries. Value Health. 2017;20 (8):1121-1130. doi:10.1016/j.jval.2017.03.011
154. WHO. Key elements for establishing a national system of HTA; 2020. Available from: https://www.who.int/health-technologyassessment/about/SYSTEMHTA/en/. Accessed January 8, 2021.

155. Gustafsson LL, Wettermark B, Godman B, et al. The 'wise list'- a comprehensive concept to select, communicate and achieve adherence to recommendations of essential drugs in ambulatory care in Stockholm. Basic Clin Pharmacol Toxicol. 2011;108(4):224-233. doi:10.1111/j.1742-7843.2011.00682.x

156. Eriksen J, Gustafsson LL, Ateva K, et al. High adherence to the 'Wise List' treatment recommendations in Stockholm: a 15-year retrospective review of a multifaceted approach promoting rational use of medicines. BMJ Open. 2017;7(4):e014345. doi:10.1136/ bmjopen-2016-014345

157. Bjorkhem-Bergman L, Andersen-Karlsson E, Laing R, et al. Interface management of pharmacotherapy. Joint hospital and primary care drug recommendations. Eur J Clin Pharmacol. 2013;69 (Suppl 1):73-78. doi:10.1007/s00228-013-1497-5

158. Yoon CH, Ritchie SR, Duffy EJ, et al. Impact of a smartphone app on prescriber adherence to antibiotic guidelines in adult patients with community acquired pneumonia or urinary tract infections. PLoS One. 2019;14(1):e0211157. doi:10.1371/journal.pone.0211157

159. Campbell SM, Kontopantelis E, Hannon K, Burke M, Barber A, Lester HE. Framework and indicator testing protocol for developing and piloting quality indicators for the UK quality and outcomes framework. BMC Fam Pract. 2011;12:85. doi:10.1186/1471-2296$12-85$

160. Lorencatto F, Charani E, Sevdalis N, Tarrant C, Davey P. Driving sustainable change in antimicrobial prescribing practice: how can social and behavioural sciences help? J Antimicrob Chemother. 2018;73(10):2613-2624. doi:10.1093/jac/dky222

161. McGinn D, Godman B, Lonsdale J, Way R, Wettermark B, Haycox A. Initiatives to enhance the quality and efficiency of statin and PPI prescribing in the UK: impact and implications. Expert Rev Pharmacoecon Outcomes Res. 2010;10(1):73-85. doi:10.1586/ erp.09.73

162. Schellack N, Bronkhorst E, Coetzee R, et al. SASOCP position statement on the pharmacist's role in antibiotic stewardship 2018. South Afr J Infect Dis. 2018;33(1):28-35. doi:10.4102/sajid. v33i1.24

163. Chigome AK, Matlala M, Godman B, Meyer JC. Availability and use of therapeutic interchange policies in managing antimicrobial shortages among South African public sector hospitals; findings and implications. Antibiotics. 2019;9(1):4. doi:10.3390/ antibiotics 9010004
International Journal of General Medicine

\section{Publish your work in this journal}

The International Journal of General Medicine is an international, peer-reviewed open-access journal that focuses on general and internal medicine, pathogenesis, epidemiology, diagnosis, monitoring and treatment protocols. The journal is characterized by the rapid reporting of reviews, original research and clinical studies across all disease areas. The manuscript management system is completely online and includes a very quick and fair peer-review system, which is all easy to use. Visit http://www.dovepress.com/ testimonials.php to read real quotes from published authors. 